\title{
Umbrella species in marine systems: using the endangered humphead wrasse to conserve coral reefs
}

\author{
Kevin C. Weng ${ }^{1, *}$, Martin W. Pedersen ${ }^{2}$, Gen A. Del Raye ${ }^{3}$, Jennifer E. Caselle ${ }^{4}$, \\ Andrew E. Gray ${ }^{3}$ \\ ${ }^{1}$ Virginia Institute of Marine Science, College of William \& Mary, Gloucester Point, Virginia 23062-1346, USA \\ ${ }^{2}$ National Institute of Aquatic Resources, Technical University of Denmark, 2920 Charlottenlund, Denmark \\ ${ }^{3}$ Pelagic Fisheries Research Program, University of Hawaii at Manoa, Honolulu, Hawaii 96822, USA \\ ${ }^{4}$ Marine Science Institute, University of California, Santa Barbara, California 93106, USA
}

\begin{abstract}
Extinction risk is closely tied to body size, home range, and species distribution. Quantifying home range is critical for conservation, and can enable the use of concepts such as 'umbrella species', whose conservation protects other species due to shared habitat. To determine the value of the humphead wrasse as an umbrella species for coral reef conservation, we conducted a multi-year study of humphead wrasse home range at Palmyra Atoll, Central Tropical Pacific, tagging juvenile, female, and male individuals with acoustic transmitters. We quantified home range using 2 metrics, length and area, and determined if these metrics were related to the sex and maturity status of the individual. We recorded individual movements during 5030 fishdays, yielding detailed records for 14 individuals comprising 3 juveniles, 5 females, and 6 males. The home range of humphead wrasse measured over a 2 yr study was 0.4 to $14 \mathrm{~km}$ and changed with ontogeny. Females had larger home ranges than other reef fishes studied to date $(n=68)$, indicating value as an umbrella species for coral reefs. We compared the home range of the species to the size distribution of tropical marine protected areas (MPAs), and used a model to estimate the MPA length necessary to retain humphead wrasse. Most MPAs are too small to effectively protect the humphead wrasse.
\end{abstract}

KEY WORDS: Focal species - Umbrella species $\cdot$ Coral reef $\cdot$ Humphead wrasse $\cdot$ Cheilinus undulatus $\cdot$ Home range $\cdot$ Protected area $\cdot$ Marine reserve

\section{INTRODUCTION}

Species loss is accelerating globally, causing concerns that we are entering the 6th mass extinction (Barnosky et al. 2011). Positive feedbacks may result in accelerating losses, since biodiversity is tied to biogeochemical properties of ecosystems and their resilience (Naeem et al. 2012). Extinction risk in vertebrates correlates with fundamental biological scales: body size, home range, and geographical distribution. Large body size is associated with enhanced extinction risk (Olden et al. 2007), as large species have lower fecundity, slower growth (Cardillo et al.

\footnotetext{
*Corresponding author: kevinweng@vims.edu
}

2005) and are more vulnerable to exploitation (Weaver et al. 1996). A larger home range is more easily fragmented and more difficult to protect (Purvis et al. 2000), and is a predictor of extinction risk (Davidson et al. 2009). A small geographical distribution enhances vulnerability to habitat loss or extreme mortality events (Davidson et al. 2009). These trends are known to occur for marine fishes (Olden et al. 2007).

In oceans, the size of a species' home range (generally considered to be the range during postrecruitment life stages, i.e. following larval dispersal) is a key predictor of the level of protection offered by marine protected areas (MPAs) (Heupel et al. 2006, Di

() The authors 2015. Open Access under Creative Commons by Attribution Licence. Use, distribution and reproduction are unrestricted. Authors and original publication must be credited. 
Franco et al. 2012). Some species range over scales of meters (Lindholm et al. 2006), whereas others range across oceans (Weng et al. 2005). Small-scale MPAs have limited effects for many fish species (Friedlander et al. 2007), particularly those that are more mobile and leave small reserves frequently (Palumbi 2004). Regions with large human populations have very low populations of large-bodied fishes, including toplevel predators, whereas areas that are effectively protected from fishing via MPAs or have a low human population density can contain a large number of toppredators (Friedlander \& DeMartini 2002, Sandin et al. 2008, Richards et al. 2012). Based on our findings and many others, a major ramping up of conservation efforts is needed (Bellwood et al. 2004).

International trade in wildlife threatens biodiversity and ecosystem function on a global scale and has caused numerous extinctions (Rosen \& Smith 2010). Illegal, unreported, and unregulated fishing (IUU) (Borit \& Olsen 2012) intersects with the wildlife trade in coral reef systems, where animals are captured alive for sale as food or aquarium animals (Poh \& Fanning 2012). Overfishing of many species is occurring, spawning aggregations are targeted (Sadovy de Mitcheson et al. 2008), and destructive fishing practices are causing severe collateral damage to reefs (Johannes \& Riepen 1995). Trade bans have failed to control overfishing on coral reefs (IUCN 2010), which face additional challenges, such as acidification, warming, pollution, and habitat degradation (Bellwood et al. 2004). The rapid economic growth of China indicates that demand for luxury seafood products will increase substantially (Fabinyi 2012).

Facing urgent conservation needs, we cannot wait for perfect ecosystem information before taking action (Johannes 1998). Conservation planning has a longer history in terrestrial settings than for oceans (King \& Beazley 2005), and the marine realm could benefit from approaches developed on land. Simply protecting areas with high diversity fails to account for the persistence of these protected systems (Nicholson et al. 2006). 'Focal species' provide greater understanding of complex systems (Lambeck 1997) and include the indicator, keystone, flagship, umbrella (Zacharias \& Roff 2001), and landscape species (Coppolillo et al. 2004) concepts. The keystone species concept aims to identify a species with the strongest role in ecosystem function, making it very difficult to identify qualifying species (Power et al. 1996). The landscape species concept aims to integrate ecological and human factors, requiring an even greater level of knowledge to apply (Sanderson et al. 2002, Coppolillo et al. 2004). Umbrella species are those with large home ranges that encompass many sympatric species with smaller ranges (Noss et al. 1996, Berger 1997). Information needs are relatively simple; we need only habitat and home-range data to identify umbrella species, a benefit in marine systems where knowledge of ecosystem function is less developed than on land. Across many taxa, the presence of umbrella species correlates with higher diversity and abundance (Branton \& Richardson 2011), demonstrating that it is a powerful conservation tool, albeit a blunt one. All focal species approaches have weaknesses and biases (Coppolillo et al. 2004, Saetersdal \& Gjerde 2011), but conservation with available knowledge is preferable to inaction (Wiens et al. 2008).

In marine systems, an umbrella species would have (1) a large home range, (2) the greatest number of sympatric species (i.e. shared habitat requirements), and (3) high vulnerability to fishing or other impacts (Berger 1997, King \& Beazley 2005, Butler et al. 2012). While an in-depth analysis of Point 2 is beyond the scope of this paper, the humphead wrasse Cheilinus undulatus shares habitat with a diverse community whose benthic habitat is itself alive - the coral reef. The species has a broad Indo-Pacific distribution (Sadovy et al. 2003a), thus occupying the region with the greatest coral reef biodiversity on the planet (Roberts et al. 2002). The humphead wrasse also fulfills Point 3, being one of the largest and most conspicuous coral reef fishes, and one severely overfished through most of its range. Targeting by the live reef fish trade has led to a severe decline in population despite its broad geographic distribution (Poh \& Fanning 2012). It is on the IUCN's 'Endangered' list, in Appendix II of the Convention on International Trade in Endangered Species (CITES), and is under consideration for listing according to the US Endangered Species Act. The humphead wrasse is the highest priced species in the live reef fish trade (Sadovy et al. 2003b), and targeting continues despite its rarity (Poh \& Fanning 2012). In the absence of home-range data it was not possible to evaluate Point 1. Only 1 publication exists on home range and movement (Chateau \& Wantiez 2007), limited to a single individual that departed the small study region after $25 \mathrm{~d}$, compromising the estimate of home range. Therefore, knowledge of the humphead wrasse's home range would allow its evaluation for all 3 umbrella species criteria.

Here we present home-range estimates for the humphead wrasse measured with an acoustic observation network. We compare these estimates to the sizes of existing MPAs in the geographic distribution 
of the species' using a retention model, and make recommendations on a MPA scale. We present both home-range area and home-range length (HRL: the longest dimension of a shape; Kramer \& Chapman 1999), and discuss the value of the humphead wrasse as an umbrella species for conservation of coral reef fishes.

\section{MATERIALS AND METHODS}

\section{Study species}

The humphead wrasse Cheilinus undulatus has a broad Indo-Pacific distribution (Sadovy et al. 2003a). It is a protogynous hermaphrodite that matures as a female at about $5 \mathrm{yr}$ of age and 35 to $50 \mathrm{~cm}$ total length (TL), with some individuals changing to mature males at about $9 \mathrm{yr}$ of age and 70 to $80 \mathrm{~cm} \mathrm{TL}$, and others remaining female (Sadovy et al. 2003a, Choat et al. 2006, Sadovy de Mitcheson et al. 2010). The species reaches $2 \mathrm{~m}$ TL and $190 \mathrm{~kg}$, and ages of at least $30 \mathrm{yr}$ (Sadovy et al. 2003a, Choat et al. 2006). The humphead wrasse eats a wide variety of invertebrate and teleost fish prey, and is notable in being one of the few predators of Acanthaster planci, the crown-of-thorns starfish (Randall et al. 1978, Sadovy et al. 2003a). Despite the large observation effort by scientists, divers, and fishers, understanding of its spawning behavior was only recently developed (Colin 2010). Only one publication exists on home range and movement (Chateau \& Wantiez 2007), limited to a single individual that departed the small study region after $25 \mathrm{~d}$, compromising the estimate of home range.

\section{Field site}

We conducted a multi-year study at Palmyra Atoll, Line Islands, Central Tropical Pacific $\left(5.9^{\circ} \mathrm{N}, 162.1^{\circ} \mathrm{W}\right)$. Palmyra is one of the few remaining parts of the world with healthy populations of humphead wrasse (Zgliczynski et al. 2013). Palmyra Atoll provided an ideal field site to test hypotheses about home-range size in large coral reef fishes due to the combination of a large-scale reef and the bordering oceanic waters that prevent emigration to other reefs. Palmyra Atoll has approximately $60 \mathrm{~km}^{2}$ of reefs and lagoons, and far exceeds the scale of the median reserve today $\left(0.4 \mathrm{~km}^{2}\right)$, as well as the previously published humphead wrasse home range length, which we estimated to be $756 \mathrm{~m}$ by measuring the width of the detection ranges in Fig. 1 of Chateau \& Wantiez (2007).

\section{Experiment}

We deployed a network of 51 acoustic receivers (VR2W, Vemco). Animals with acoustic transmitters (V9, V13, and V16 coded tags, 2 min delay, 193 to $3033 \mathrm{~d}$ battery life) were detected when inside the detection radius of a receiver yielding presenceabsence data. Fish were tagged in 2010 and 2011, and receivers were downloaded in 2011 and 2012. The network covered all habitats of the atoll (i.e. lagoons, forereef, and backreef areas).

Fish were captured with hooks or by divers using nets, and were placed in a holding tank aboard a boat. Anesthesia was conducted using MS-222; a small incision was made in the abdomen, a transmitter was inserted, and the wound was closed using surgical suture. Transmitters and instruments were soaked in povidone-iodine solution. Following surgery fish were placed in the holding tank to recover before being released.

\section{Sex of study individuals}

We were not able to determine sex based on morphology because there is no clear sexual dimorphism in the species (Liu \& Sadovy de Mitcheson 2011), and we did not want to risk injuring animals by attempting to take gonadal samples. Therefore, we used the data in Table II of Sadovy de Mitcheson et al. (2010) to calculate mean TL for juvenile, female, or male individuals (means were: juvenile, $33.8 \mathrm{~cm}$; mature female, $77.9 \mathrm{~cm}$; and mature male, $104.6 \mathrm{~cm}$ ). Then, using a $k$-means clustering algorithm with mean TL as input, we classified each of our animals into these 3 classes. We then compared the HRL with class using an ANOVA to check if differences in HRL could be detected between classes. The possibility of primary males $<85 \mathrm{~cm}$ TL exists (Colin 2010, Sadovy de Mitcheson et al. 2010), so we cannot rule out the possibility that individuals categorized as female were small primary males. In addition, the existence of rare large females (Sadovy de Mitcheson et al. 2010) means there is a possibility that individuals we classified as male were actually female.

\section{Data analysis}

We quantified home range using 2 metrics, length and area, and determined if these metrics were related to the total length of the individual. Many animals have asymmetric ranges, so the scale neces- 
sary for protection is given by the largest distance to span the home range - the HRL (the distance between boundaries in the longest dimension; Kramer \& Chapman 1999). We also calculated home-range area, since many MPAs are categorized by area rather than length. Data were not normally distributed, so we used median and interquartile ranges to report results.

We used 2 different approaches to determine HRL and area: the kernel utilization distribution (KUD) and the minimum convex polygon (MCP). Since the KUD method is less sensitive to outliers, we report KUD values in the results, and both in Table 1 . These methods were applied to locations from each animal calculated at evenly distributed time points using a weighted mean method (Simpfendorfer et al. 2002). Because of the large number of detections (see Table 1), and because of the relative insensitivity of HRL and area to the choice of bandwidth, we used the 'ad hoc' method for selecting the KUD bandwidth, which is appropriate for large sample sizes
(Worton 1989). For calculation of both MCP and KUD we used the package adehabitat for R Version 3 (R Core Team 2013).

HRL was calculated as the longest dimension of the $95 \% \mathrm{KUD}$, or the longest dimension of the MCP. We then compared HRL with TL using a quadratic regression (with regression parameters beta ${ }_{0}$, beta ${ }_{1}$, and beta $_{2}$ ) to check for significant ontogenetic or sexbased effects. To check the hypothesis that HRL depends quadratically on TL we fitted the model such that:

$$
\mathrm{HRL} \sim \text { beta }_{0}+\text { beta }_{1} \times \mathrm{TL}+\text { beta }_{2} \times \mathrm{TL}^{2}
$$

To determine if our study duration was sufficient to allow for meaningful inference regarding home range, we checked that HRL reached an asymptotic value indicating that extending the study duration would not yield different results. Starting with $1 \mathrm{~d}$ of data we calculated $95 \% \mathrm{HRL}$, and repeated for increasingly larger data subsets to produce a cumulative home-range length over time (Heupel et al. 2004).

Table 1. Home range metrics for humphead wrasse Cheilinus undulatus. Home range length (HRL) is based on $95 \%$ kernel utilization distribution (KUD) or on minimum convex polygon (MCP). ID: identification number; F: female; M: male; J: juvenile; Q1: 1st quartile; Q3: 3rd quartile

\begin{tabular}{|c|c|c|c|c|c|c|c|c|}
\hline Tagging date & $\begin{array}{c}\text { Fish } \\
\text { ID }\end{array}$ & $\begin{array}{l}\text { Total } \\
\text { length } \\
(\mathrm{cm})\end{array}$ & $\begin{array}{l}\text { Track } \\
\text { days }\end{array}$ & $\begin{array}{l}\text { HRL-95\% } \\
\text { KUD }(\mathrm{km})\end{array}$ & $\begin{array}{l}\text { HRL-MCP } \\
\quad(\mathrm{km})\end{array}$ & $\begin{array}{l}\text { Area } 95 \% \\
\text { KUD }\left(\mathrm{km}^{2}\right)\end{array}$ & $\begin{array}{c}\text { Area MCP } \\
\quad\left(\mathrm{km}^{2}\right)\end{array}$ & $\begin{array}{l}\text { Days to } \\
\text { asymptote of } \\
\text { HRL-MCP }\end{array}$ \\
\hline 9 Aug 2011 & F1 & 77 & 394 & 14.4 & 14.4 & 5.6 & 21.3 & 331 \\
\hline 12 Aug 2011 & $\mathrm{~F} 2$ & 61 & 362 & 9.2 & 9.4 & 2.9 & 7.7 & 307 \\
\hline 15 Aug 2011 & F3 & 67 & 371 & 14.4 & 18.8 & 5.9 & 43.9 & 329 \\
\hline 18 Aug 2011 & $\mathrm{~F} 4$ & 66 & 340 & 7.0 & 6.6 & 5.3 & 6.2 & 37 \\
\hline 24 Aug 2011 & F5 & 83 & 380 & 10.3 & 9.7 & 9.0 & 15.5 & 166 \\
\hline 15 Nov 2010 & $\mathrm{~J} 2$ & 41 & 375 & 0.7 & 2.1 & 0.1 & 0.5 & 179 \\
\hline 17 Nov 2010 & J3 & 32 & 374 & 0.8 & 0.8 & 0.1 & 0.2 & 36 \\
\hline 22 Aug 2011 & $\mathrm{~J} 6$ & 28 & 202 & 0.4 & 0.4 & 0.0 & 0.0 & 186 \\
\hline 16 Nov 2010 & M1 & 103 & 349 & 3.7 & 3.6 & 0.9 & 4.0 & 71 \\
\hline 17 Aug 2011 & M3 & 107 & 372 & 3.3 & 5.6 & 0.4 & 14.6 & 61 \\
\hline 19 Aug 2011 & M4 & 87 & 386 & 2.0 & 4.3 & 0.2 & 8.1 & 117 \\
\hline 20 Aug 2011 & M5 & 100 & 385 & 2.1 & 4.4 & 0.4 & 4.5 & 107 \\
\hline 25 Aug 2011 & M6 & 109 & 378 & 4.3 & 5.6 & 3.3 & 14.6 & 172 \\
\hline 26 Aug 2011 & M7 & 89 & 362 & 2.5 & 1.9 & 1.4 & 1.9 & 21 \\
\hline All & $\begin{array}{c}\text { Median } \\
\text { Q1 } \\
\text { Q3 }\end{array}$ & $\begin{array}{l}80.0 \\
62.3 \\
97.3\end{array}$ & $\begin{array}{l}373.0 \\
362.0 \\
379.5\end{array}$ & $\begin{array}{l}3.5 \\
2.0 \\
8.6\end{array}$ & $\begin{array}{l}5.0 \\
2.5 \\
8.7\end{array}$ & $\begin{array}{l}1.2 \\
0.2 \\
4.8\end{array}$ & $\begin{array}{c}7.0 \\
2.4 \\
14.6\end{array}$ & $\begin{array}{c}142 \\
64 \\
184\end{array}$ \\
\hline Females & $\begin{array}{c}\text { Median } \\
\text { Q1 } \\
\text { Q3 }\end{array}$ & $\begin{array}{l}67.0 \\
66.0 \\
77.0\end{array}$ & $\begin{array}{l}371.0 \\
362.0 \\
380.0\end{array}$ & $\begin{array}{c}10.3 \\
9.2 \\
14.4\end{array}$ & $\begin{array}{c}9.7 \\
9.4 \\
14.4\end{array}$ & $\begin{array}{l}5.6 \\
5.3 \\
5.9\end{array}$ & $\begin{array}{c}15.5 \\
7.7 \\
21.3\end{array}$ & $\begin{array}{l}307.0 \\
166.0 \\
329.0\end{array}$ \\
\hline Juveniles & $\begin{array}{c}\text { Median } \\
\text { Q1 } \\
\text { Q3 }\end{array}$ & $\begin{array}{l}32.0 \\
30.0 \\
36.5\end{array}$ & $\begin{array}{l}374.0 \\
288.0 \\
374.5\end{array}$ & $\begin{array}{l}0.7 \\
0.6 \\
0.7\end{array}$ & $\begin{array}{l}0.8 \\
0.6 \\
1.4\end{array}$ & $\begin{array}{l}0.1 \\
0.1 \\
0.1\end{array}$ & $\begin{array}{l}0.2 \\
0.1 \\
0.4\end{array}$ & $\begin{array}{l}179.0 \\
107.5 \\
182.5\end{array}$ \\
\hline Males & $\begin{array}{c}\text { Median } \\
\text { Q1 } \\
\text { Q3 }\end{array}$ & $\begin{array}{c}101.5 \\
91.8 \\
106.0\end{array}$ & $\begin{array}{l}375.0 \\
364.5 \\
383.3\end{array}$ & $\begin{array}{l}2.9 \\
2.2 \\
3.6\end{array}$ & $\begin{array}{l}4.4 \\
3.8 \\
5.3\end{array}$ & $\begin{array}{l}0.7 \\
0.4 \\
1.3\end{array}$ & $\begin{array}{c}6.3 \\
4.1 \\
13.0\end{array}$ & $\begin{array}{c}89.0 \\
63.5 \\
114.5\end{array}$ \\
\hline
\end{tabular}




\section{MPA size}

We used a global protected area dataset (IUCN \& UNEP 2009) to determine the area and boundaries of tropical MPAs. To limit the analysis to MPAs containing coral reefs, we excluded all protected areas that did not overlap with the coral reef polygons contained in a coral reef dataset (Burke \& Spalding 2011). Using the geographic distribution reported in Sadovy et al. (2003a), we calculated MPA length for each of the coral reef MPAs within the range of the humphead wrasse. MPA length was defined as the largest linear dimension of the protected area, and was calculated using a rotating calipers method on the minimum convex polygon enclosing the MPA.

To compare MPA length against the home-range scale of humphead wrasse, we estimated juvenile, male, and female retention rates for different sizes of MPAs. Our simulations were conducted for putative MPAs across a large range of sizes, and not for specific MPAs that exist around the world. We assumed a linear coastline with uniform habitat (Moffitt et al. 2009), and simulated the spatial distribution of fish home ranges as a uniform random variable. This means that the individual fish was the same as its home range, for the purposes of the simulation, and that the distribution of fish was random. The number of individuals simulated was a function of the viable population size for a species, so resource managers should chose a number appropriate for their case. We created random simulations of homerange distribution $\left(n=10000\right.$ home ranges $\left.\mathrm{run}^{-1}\right)$ in MPAs of different length ( $L$, in units of HRL) and defined home range $(R)$ as the sum of all home ranges or parts of home ranges expected to fall within the MPA divided by the sum of all the home ranges. We used a large number of individual fish per run $(10000)$ to ensure that results were not controlled by stochastic processes.

$$
R=\frac{\sum_{i=1}^{n} \int_{I_{i}}^{r_{i}} g(x)}{n H}
$$

where $n$ is the total number of simulated home ranges $(10000), i$ is the $i^{\text {th }}$ home range, $H$ is the HRL (which can be treated as 1), $x$ is the length coordinate and $g(x)$ is a function defined to equal $H^{-1}$ inside the bounds of the MPA (situated along the line from 0 to $L$ ), and equals 0 outside of it:

$$
g(x)=\left\{\begin{array}{c}
H^{-1}, 0 \leq x \leq L \\
0, x<0 \\
0, x>L
\end{array}\right.
$$

while $l_{i}$ and $r_{i}$ are the left and right bounds of the $i^{\text {th }}$ home range, defined as the home-range center $\left(h_{i}\right)$ minus and plus half the HRL, respectively:

$$
\begin{aligned}
& l_{i}=h_{i}-\frac{H}{2} \\
& r_{i}=h_{i}+\frac{H}{2}
\end{aligned}
$$

While home ranges in reality are not uniformly distributed due to the uneven distribution of suitable habitat, the distribution of habitat should not affect the expected behavior of our simulation (i.e. patchy habitat distributions are equally likely to reduce or increase retention). The results of our analysis differed for 2 conditions: in the first condition, we constrained the home ranges to be distributed so that their centers always overlapped with the MPA:

$$
h \sim U(0, L)
$$

This was termed the 'narrow' condition and implies that only fish whose home-range centers fall within an MPA can be considered for calculations of retention rate. In the second condition (the 'wide' condition), we additionally allowed the home ranges to be distributed so that their edges overlapped the MPA:

$$
h \sim U\left(\frac{-H}{2}, L+\frac{H}{2}\right)
$$

This more conservative definition, which considers more individuals for calculations of retention rate, always resulted in lower estimates for retention. Both calculations yielded an MPA length (in units of HRL) necessary to achieve a given level of postrecruitment retention. Following a published method (Kramer \& Chapman 1999), we chose $90 \%$ retention of individuals inside the MPA as the target $(\mathrm{R} \geq 0.9)$, but decision makers should choose a target level appropriate to their case. HRLs are a strong function of ontogeny. MPAs that seek to boost the spawning biomass of a species must successfully protect all 3 post-recruitment life stages; therefore, the life stage with the largest HRL (female) was considered to set the MPA length threshold for successful protection.

\section{RESULTS}

We captured and tagged 19 humphead wrasse ranging in size from 27 to $109 \mathrm{~cm}$ TL $(80 \mathrm{~cm}$; $62-$ $97 \mathrm{~cm}$ TL [median; Q1-Q3]) during expeditions in 2010 and 2011 at Palmyra Atoll (Table 1). During 5030 fish-days, 188585 detections were recorded, 
yielding detailed movement records for 14 individuals comprising 3 juveniles, 5 females, and 6 males (Fig. 1, Table 1). Home-range metrics were calculated from both KUDs and MCPs; the methods yielded similar values for HRL, but MCP provided larger estimates for area. We report results from KUDs, for which bandwidths averaged $0.06 \mathrm{~km}$ (median; Q1-3: 0.03 to $0.13 \mathrm{~km}$ ).

\section{Home-range scale and ontogeny}

The overall KUD-HRL was $3.5 \mathrm{~km}$ (median; Q13: $2.0-8.6 \mathrm{~km}$; Table 1). HRL varied by stage
(Kruskal-Wallis test: $H=11.31$, df $=2, \mathrm{p}=0.00$ ), and was $0.7 \mathrm{~km}(0.6-0.7 \mathrm{~km})$ for juveniles, $10.3 \mathrm{~km}$ $(9.2-14.4 \mathrm{~km})$ for females, and $2.9 \mathrm{~km}(2.2-3.6 \mathrm{~km})$ for males (Fig. 2). Since females had the largest range, they would not be protected by management regimes based on male or juvenile homerange scale. Therefore, females were used to quantify the area required to protect a population. Quadratic regression of HRL versus TL provided a significant fit $\left(\mathrm{R}^{2}=0.689\right.$; $t$-test for beta $2: t=-4.17$, $\mathrm{p}=0.00)$. That is, for individuals below a peak value $(77 \mathrm{~cm}$ TL) HRL increased as a function of $\mathrm{TL}$, whereas individuals $>77 \mathrm{~cm}$ showed a decrease in HRL.

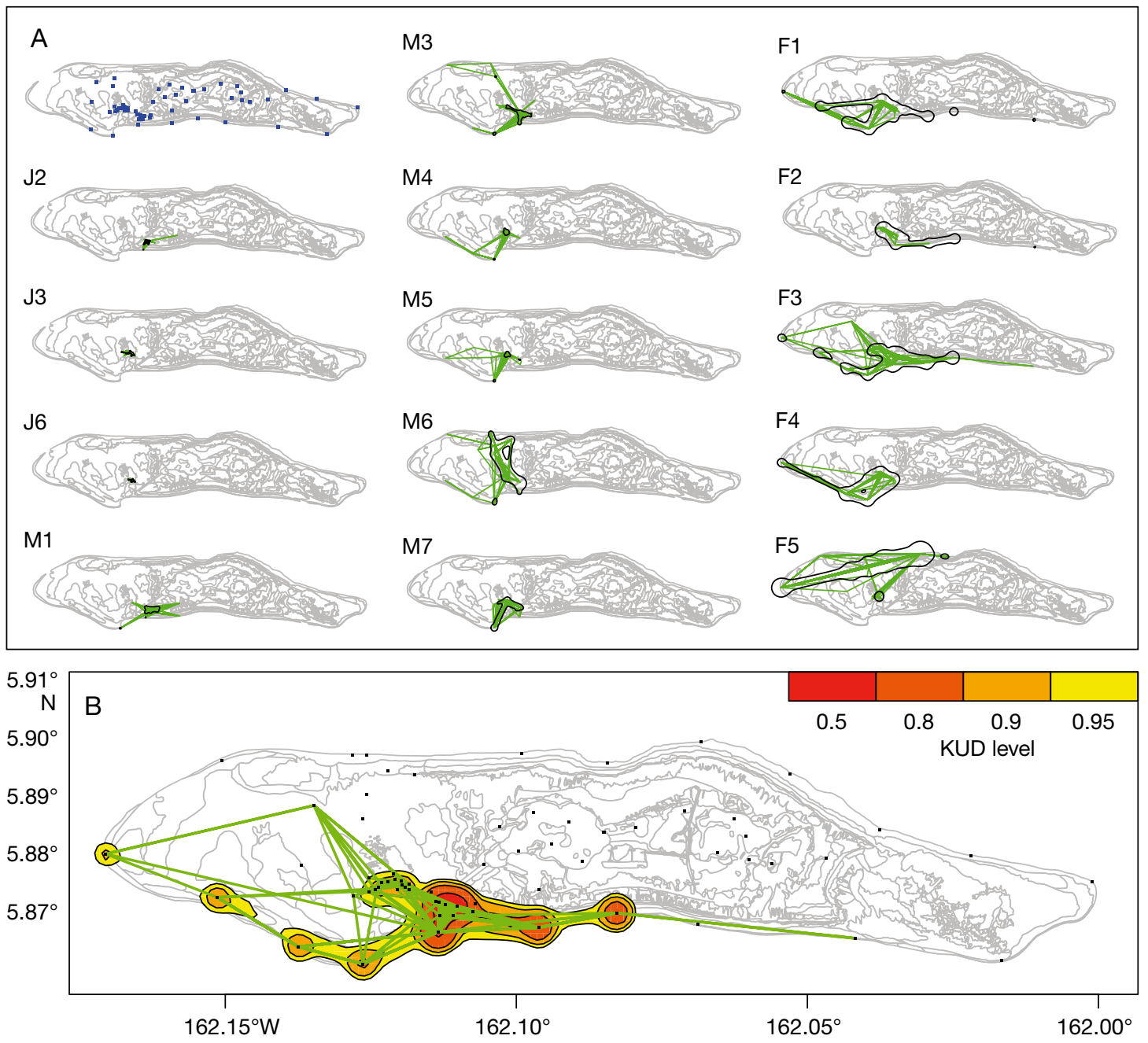

Fig. 1. (A) Home ranges of 14 humphead wrasse Cheilinus undulatus at Palmyra Atoll (grey outlines show contours from 0 to $20 \mathrm{~m}$ ). Track durations ranged from 202 to $394 \mathrm{~d}$. Upper left panel shows nodes of the receiver network; other panels show individual fish. Identification numbers correspond to Table 1 (J: juvenile; M: male; F: female). Green lines show estimated locations used to calculate minimum convex polygons and kernel utilization distributions (KUD). Black outline shows $95 \% \mathrm{KUD}$, area, and length given in Table 1. (B) KUD for 1 individual (F3) that was $67 \mathrm{~cm}$ total length at time of tagging, tracked for $371 \mathrm{~d}$ 

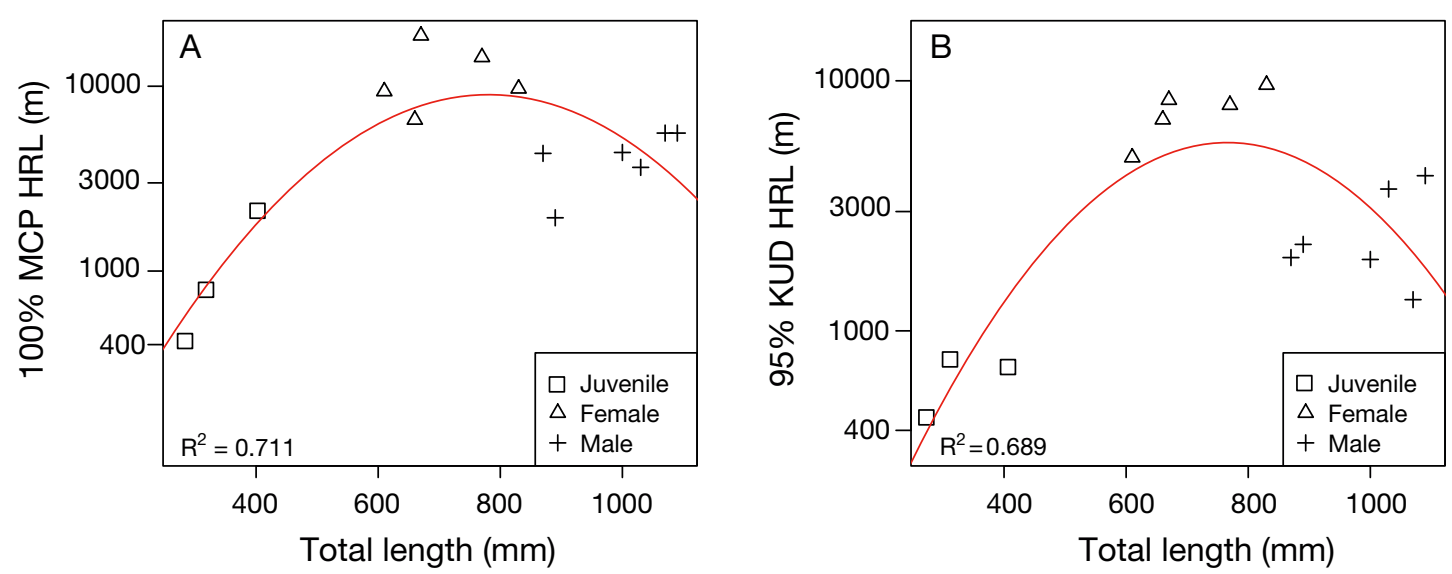

Fig. 2. Home range versus body size in the humphead wrasse Cheilinus undulatus. (A) Home-range length (HRL) based on minimum convex polygons (MCP), versus total length. (B) HRL using the $95 \%$ kernel utilization distribution (KUD) method, versus total length. The red line shows a nonlinear fit to the data, while the assignment of life-stage was made using a k-means clustering algorithm (see 'Materials and methods'). Significant differences exist between life stages

\section{Home-range scale of coral reef fishes}

The humphead wrasse had a greater HRL than other coral reef teleost fishes from a wide variety of families (Fig. 3), including the heavily targeted groups Serranidae, Carangidae, Scaridae, Mullidae, and Acanthuridae (Kramer \& Chapman 1999). In particular, the median home-range scale of female humphead wrasse $(9.7 \mathrm{~km})$ to our knowledge exceeds all other measured HRLs of coral reef fishes, including those reported for juvenile reef sharks of considerably larger body size (Fig. 3; Table S1 in the Supplement at www.int-res.com/articles/suppl/

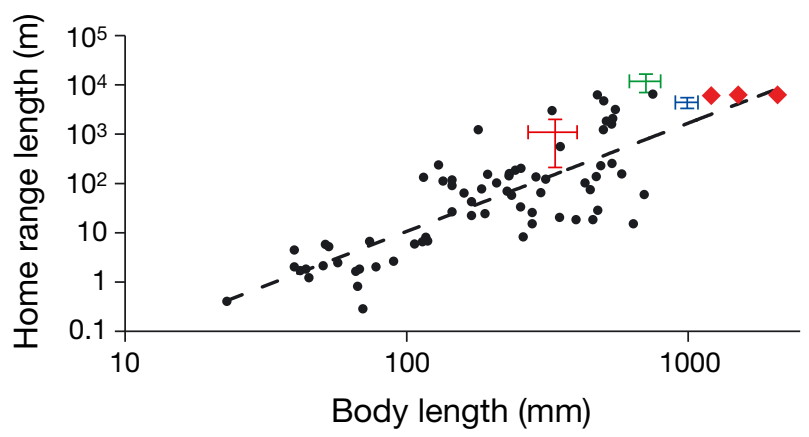

Fig. 3. Home-range length (HRL) versus body length for coral reef fishes: 68 species of coral reef teleosts (black circles) and 3 sharks (red diamonds) from the literature (see Table S1 in the Supplement), and data from this study (crosses) for humphead wrasse Cheilinus undulatus showing juveniles (red), females (green), and males (blue) $( \pm 1$ $\mathrm{SD}$ ). Dashed line shows a power law regression of the form $y=k L^{b}$. The regression has a slope of 2.20 (95\% CI: 1.83-2.57) and explains $66 \%$ of the variability in the data. Humphead wrasse HRL exceeds that of other teleost reef fishes and falls above the regression line n027p251_supp.pdf). Using a power-law regression between HRL and body length for 68 coral reef fishes, we calculated that the juvenile, female, and male HRLs are 6.7, 16.7, and 2.9 times larger than expected based on body length alone.

\section{Home-range scale and marine protected areas}

We used 2 metrics to evaluate the scale of existing MPAs, based on how many individuals are considered in retention-rate calculations, with the narrow condition being less conservative than the 'wide' condition (see 'Materials and methods'). Our calculations of expected retention rate indicate that the minimum MPA length necessary to achieve $90 \%$ retention of female humphead wrasse (median HRL: $9.7 \mathrm{~km}$ ) is $24.3 \mathrm{~km}$, or 2.5 times the HRL under the narrow condition, which considers fewer individuals, and $87.3 \mathrm{~km}$, or 9 times the HRL under the wide (conservative) condition, which considers more individuals (Fig. 4). Of the 2028 coral reef MPAs that have been established inside the known range of Cheilinus undulatus, $23.0 \%$ of the MPAs meet the size criterion for $90 \%$ retention under the narrow condition and $5.3 \%$ meet the criterion for the wide condition (Fig. 5).

\section{Temporal and spatial adequacy of study}

Home ranges for all animals were limited in size compared to the size of the study area (Fig. 1). Palmyra's coral reef platform is $19.5 \mathrm{~km}$ long based 

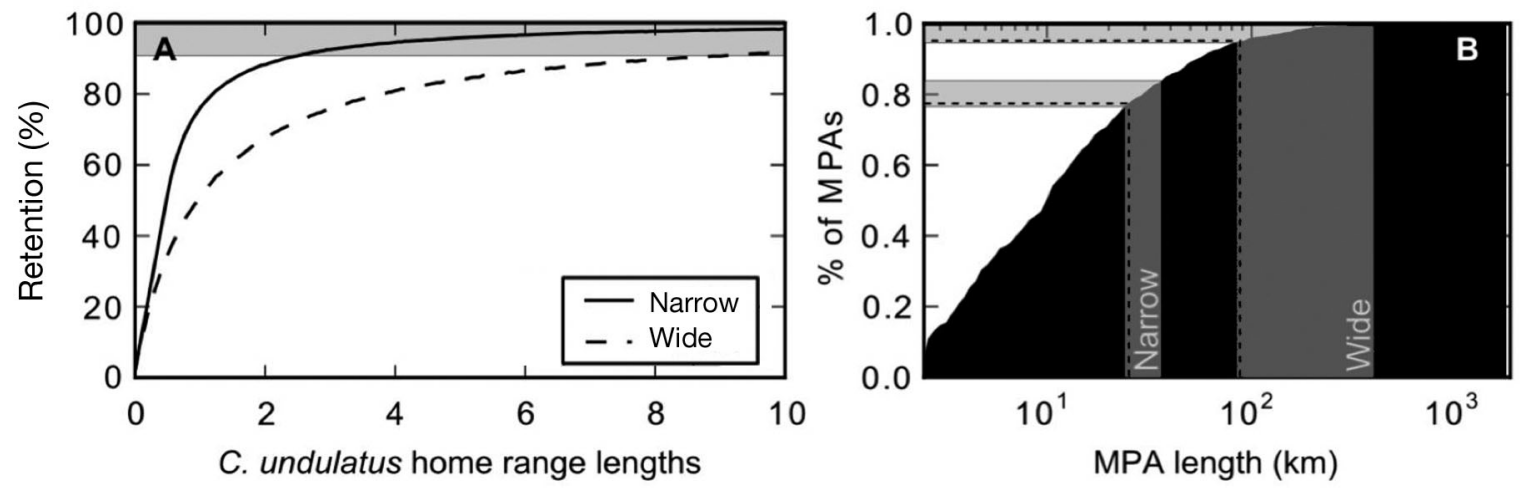

Fig. 4. Marine protected area (MPA) length thresholds for humphead wrasse Cheilinus undulatus. (A) MPA length to achieve $90 \%$ retention of post-recruitment individuals in units of female home range length (HRL). Gray indicates MPA lengths with retention $>90 \%$. Length axis in multiples of HRL to show that MPA size scales with the species being considered. Narrow and wide conditions are shown (see 'Materials and methods'). (B) HRL for females versus size of MPAs within the species' range. Black polygon shows the cumulative frequency distribution of MPA size. Gray shading and black dashed lines show the interquartile range and median MPA lengths with $90 \%$ retention of females, respectively. Females are presented as they have the longest HRL and would not be protected by MPAs designed for males or juveniles. The percentage of MPAs meeting the narrow and wide conditions for median female HRL are 23.0 and $5.3 \%$, respectively

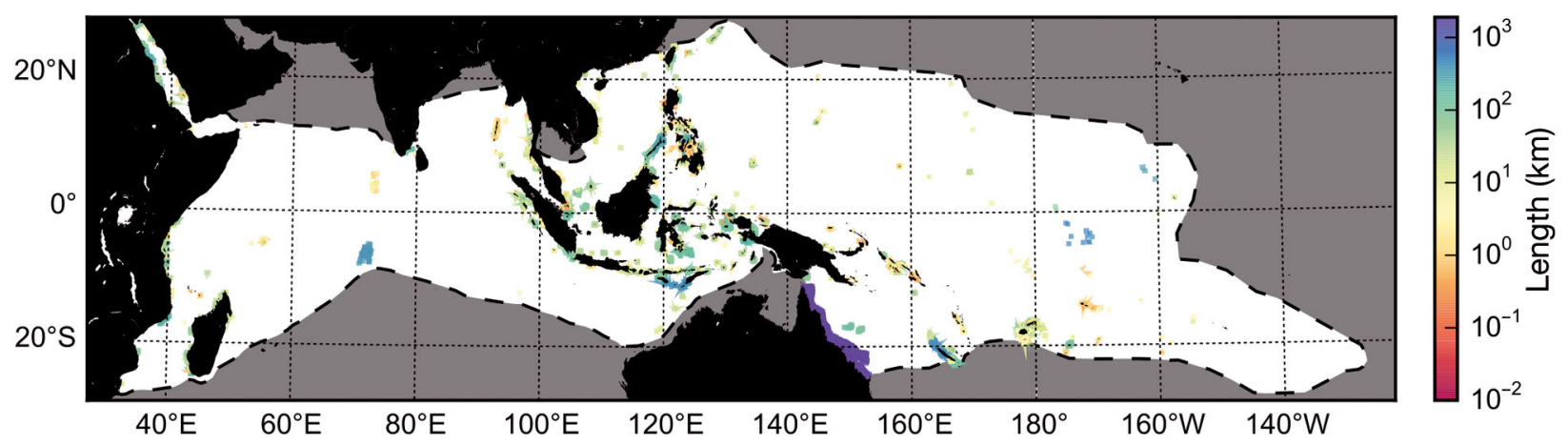

Fig. 5. Length dimensions for marine protected areas (MPAs) in the Indo-Pacific region. Region bounded by dashed line shows the geographic distribution of humphead wrasse Cheilinus undulatus after Sadovy et al. (2003). The color of MPAs is scaled to their length. Of the MPAs, 77 to $94 \%$ are too small to achieve $90 \%$ retention of female hunphead wrasse

on NOAA high-resolution bathymetry (www.soest. hawaii.edu/pibhmc/pibhmc_pria_pal_bathy.htm). The median HRL was significantly smaller than $19.5 \mathrm{~km}$ (left-tailed sign rank test: $W=0, p=0.00$; we used non-parametric tests because the distribution of HRL is non-normal, Jarque-Bera test: $J B=3.01, \mathrm{p}=0.05$ ). This indicates that our study site was large enough to obtain unbiased estimates of HRL.

Tracking durations for the 14 individuals ranged from 202 to $394 \mathrm{~d}$ and averaged $373 \mathrm{~d}$ (median) (Quartile 1 to 3: 362 to 379 d). Calculating HRL for increasingly larger subsets of data indicated that HRL reached an asymptote for most individuals at a median of $142 \mathrm{~d}$ (Quartile 1 to 3: 64 to $184 \mathrm{~d}$; Table 1). The median tracking duration was greater than the median time to asymptote (right-tailed sign rank test: $W=105, \mathrm{p}=0.00)$, indicating that the temporal extent of the study was sufficient to quantify HRL. To deter- mine if animals had a fixed home range that shifted spatially through time (thereby causing HRL to increase through time), we also calculated HRL using moving windows of $1,2,7$, and $14 \mathrm{~d}$. The maximum HRL during the window width was not significantly different from the maximum HRL across the whole record (Kruskal-Wallis test: $H=0.55$, df $=4, \mathrm{p}=$ 0.969).

\section{DISCUSSION}

Our data reveal that the humphead wrasse has a well-defined home range that exceeds the scale of most existing MPAs globally. In the face of growing international demand for wildlife products, protection of the humphead wrasse will require much stronger conservation actions. Such actions would 
also have major benefits in terms of safeguarding habitat for the entire ecosystem in which the humphead wrasse lives. The humphead wrasse fulfills 3 key criteria for an umbrella species (Caro \& O'Doherty 1999, Roberge \& Angelstam 2004): a larger home range than sympatric species, a habitat shared with the most diverse coral reef communities (Roberts et al. 2002), and high vulnerability to fishing (Sadovy et al. 2003a). Key considerations for the design of marine reserves and networks include habitat representation, risk, critical areas, MPA spacing, duration, and climate-change resilience (Green et al. 2014). Larval dispersal is an important consideration for the spacing distance between MPAs; while the key ecological determinant for the scale of any individual MPA is the home range of one or more target species (Palumbi 2004). In this study, we focus on the latter question, and the implications of new data on the home range of the humphead wrasse.

\section{Home range of humphead wrasse and the scale of existing marine reserves}

Most existing MPAs are too small to protect the humphead wrasse (Figs. 4 \& 5). Globally, reserves range from 0.004 to $640000 \mathrm{~km}^{2}$, but the average is small in scale, 1 to $10 \mathrm{~km}^{2}$ (IUCN \& UNEP 2009). Considerations for the design of reserves and reserve networks include size, spacing, and shape, with the aim of maintaining ecosystem function in the face of fishing, pollution, development, natural disasters, and climate change (Botsford et al. 2003, Friedlander et al. 2003, Shanks et al. 2003, Palumbi 2004, Fernandes et al. 2005, McLeod et al. 2009). The size of reserves should be related to the home range of key species, while the spacing of reserves should be related to distances of larval connectivity (Palumbi 2004). Furthermore, different functional groups and size classes have contrasting responses to marine reserves, with more-predatory and large body-sized species increasing the most after protection and some groups decreasing as a result of predation and other factors (Micheli et al. 2004).

The existing literature suggests that coral reef MPAs should be 4 to $20 \mathrm{~km}$ in length (Friedlander et al. 2003, Shanks et al. 2003, Palumbi 2004, Fernandes et al. 2005, McLeod et al. 2009). Our results suggest that MPAs should be roughly an order of magnitude larger (20 to $80 \mathrm{~km}$ length) to protect the humphead wrasse. Given this, what benefits would accrue to coral reef ecosystems by scaling up MPAs to protect humphead wrasse?
Comparison of our home-range data with the literature shows that the humphead wrasse is an effective umbrella species for coral reef ecosystems. The median HRL of female humphead wrasse $(10.3 \mathrm{~km})$ exceeds all other published HRLs of coral reef teleost fishes, including the heavily targeted families (Fig. 3; references in Table S1). Since this species falls above the body size-home range regression for coral reef fishes, it has more value as an umbrella species than indicated by its size. To realize the conservation benefits of using the humphead wrasse as an umbrella species, a major scaling-up of MPAs will be required. Geographically, the greatest threats to coral reefs overlap with the smallest MPAs in the Coral Triangle (Fig. 5), indicating that this region is of particular concern. The $344000 \mathrm{~km}^{2}$ Great Barrier Reef Marine Park (GBRMP), which constitutes one of the largest MPAs in the world, implemented a zoning plan in 2004 which establishes $20 \mathrm{~km}$ as the minimum length of the smallest dimension of any no-take reserve, and, as of 2005, nearly half of the 122 offshore reserves in the GBRMP had been expanded to fit this definition (Fernandes et al. 2005). The use of humphead wrasse as an umbrella species would emphasize similar, or more conservative, standards in spatial management systems for coral reefs across the Indo-Pacific.

\section{Extinction risk in marine fishes}

How likely is extinction in marine fishes? Due to large ranges and high dispersal and fecundity, marine extinctions were considered unlikely in the past. However, both extinctions and major range contractions have occurred among marine fishes (Carlton et al. 1999, Dulvy et al. 2003, Sadovy \& Cheung 2003). For those species that command unusually high prices, management via Adam Smith's 'invisible hand' does not work (Thornton 2009). The perception of rarity can increase the value of such products (Hall et al. 2008), so hunters and fishers continue to target such species when rare (Price \& Gittleman 2007). The humphead wrasse and many sympatric species exist across a vast area of the Indo-Pacific Ocean, so fisheries have little chance of causing extinctions. However, massive habitat loss is possible in the near future, resulting from ocean acidification and compounding stressors (Kleypas et al. 1999, Orr et al. 2005, Doney et al. 2009), meaning that species with large present-day geographic distributions may have small or patchy distributions in the future. Given the potential for such changes, maintaining systems in 
their most intact form appears to be a sensible strategy for coral reef resilience.

Reviews of marine extinction highlight species distribution scale as a predictor of risk, but do not discuss individual home ranges. Specific traits are correlated with extinctions (Dulvy et al. 2004), including rarity (Musick et al. 2000), large body size, late maturity (Reynolds et al. 2005), specialized habitat (Musick et al. 2000), narrow depth range (Graham et al. 2011), small geographic range, endemism, sexchanging ontogeny, and trophic category (macrocarnivores and mobile invertivores) (Bender et al. 2013). Small body size has also been highlighted (Graham et al. 2011), although this study excluded families such as groupers, snappers, and jacks that skew towards large body size. High fecundity alone does not appear to impart resilience to extinction (Reynolds et al. 2005). Naturally rare reef fish species may be targeted more intensely by predators and wiped out of some localities (Almany 2004). Our results suggest that, in the context of a human-dominated ocean, where human predation can be a key factor shaping community structure, a large home range may increase susceptibility to extinction. Island specialists may have evolved traits for more consistent recruitment than congeners living in extended reef systems, potentially reducing vulnerability (Hobbs et al. 2011). Which of these traits occur in the humphead wrasse? Rarity, large body size, sex-changing ontogeny, and trophic category all put the humphead wrasse on the vulnerable end of the spectrum, while its large species distribution and moderate age at maturity may provide resilience. Many species that are resilient to fishing may have numerous natural refugia (Sadovy \& Cheung 2003), but the broad accessibility of coral reefs means that legal or cultural refugia are necessary.

\section{Empowering conservation actions}

Global challenges are increasing for marine species and ecosystems (Harnik et al. 2012). As innovations occur in marine conservation and planning (Campagna et al. 2007, Stelzenmuller et al. 2013), we require accurate biological information on which to base new conservation strategies. While we aspire to manage optimally, acting before species or ecosystems are lost means we must manage using the levers we can pull, such as the CITES and the US Endangered Species Act (Harris 2012). Levers also exist where international, national, regional, and local entities are creating and modifying laws, rules, and customs for the management of fisheries and the conservation of ecosystems (Weeks et al. 2014). Whether the actions are being taken by traditional leaders, fishery cooperatives, governments, non-governmental organizations, or international bodies, the biology remains the same, so conservation actions must be informed by the best available information, and 'scientific advances in fish connectivity ... necessitate refining advice for marine reserve design' (Green et al. 2014, p. 143).

Limited understanding of ecosystem function may make it difficult to find keystones, and systems with high functional redundancy may not have keystone species. In contrast to a keystone species concept, the umbrella species concept does not address the ecological role of a species, or the level of functional redundancy in the ecosystem. It simply addresses the number of other species that are sympatric with the candidate species (Noss et al. 1996, Berger 1997). The umbrella species concept provides us a way to understand the broader implications of the protection of an endangered species. If we protect the habitat of an endangered species with few sympatric species, the system as a whole derives little benefit, whereas habitat protection for an umbrella species, which has many sympatric species, generates great benefits to the ecosystem. Hence, where endangered species are also effective umbrella species, they become the surrogate of an entire ecosystem (Caro \& O'Doherty 1999).

The umbrella species concept can be used to develop suites of species that are more representative of ecosystems than single species (Coppolillo et al. 2004), and can be validated through investigations of whether umbrella species and co-occurring species respond similarly to stressors, and to what degree species co-occur (Saetersdal \& Gjerde 2011). While umbrella species may not exist for all systems, they are effective in some (Butler et al. 2012, Nicholson et al. 2013), and the concept allows us to act sooner than is possible with the keystone species concept, which requires exhaustive knowledge of functional roles. We suggest that the humphead wrasse, with its large home range and threatened status, can act as an umbrella species for enhanced conservation of coral reef fishes and their habitat.

Acknowledgements. Research at Palmyra Atoll was funded by a grant to K.C.W. from NOAA's Undersea Research Program and Coral Reef Conservation Program, and the Hawaii Undersea Research Laboratory pursuant to Project Number NA05OAR4301108 and NA09OAR43002. Additional support was provided by the Pelagic Fisheries Research Program (PFRP) under Cooperative Agreement NA09OAR 4320075 between the Joint Institute for Marine and Atmos- 
pheric Research (JIMAR) and the National Oceanic and Atmospheric Administration (NOAA). The views expressed herein are those of the authors and do not necessarily reflect the views of NOAA or any of its subdivisions. It was permitted by the US Fish and Wildlife Service and the University of Hawaii Institutional Animal Care and Use Committee. We thank The Nature Conservancy, the Palmyra Atoll Research Consortium, D. Lau, J. Muir, A. Purves, L. Itano, C. Comfort, A. Meyer, S. White, K. Pollock, K. Hum, B. Santos, S. Case, J. Smith, K. Puglise, and B. Taylor. This paper is Contribution No. 3455 of the Virginia Institute of Marine Science, College of William \& Mary, and number PARC-0112 from the Palmyra Atoll Research Consortium.

\section{LITERATURE CITED}

- Almany GRWM (2004) Odd species out as predators reduce diversity of coral-reef fishes. Ecology 85:2933-2937

> Barnosky AD, Matzke N, Tomiya S, Wogan GO and others (2011) Has the Earth's sixth mass extinction already arrived? Nature 471:51-57

> Bellwood DR, Hughes T, Folke C, Nyström M (2004) Confronting the coral reef crisis. Nature 429:827-833

> Bender MG, Floeter SR, Mayer FP, Vila-Nova DA and others (2013) Biological attributes and major threats as predictors of the vulnerability of species: a case study with Brazilian reef fishes. Oryx 47:259-265

Berger J (1997) Population constraints associated with the use of black rhinos as an umbrella species for desert herbivores. Conserv Biol 11:69-78

> Borit M, Olsen P (2012) Evaluation framework for regulatory requirements related to data recording and traceability designed to prevent illegal, unreported and unregulated fishing. Mar Policy 36:96-102

> Botsford LW, Micheli F, Hastings A (2003) Principles for the design of marine reserves. Ecol Appl 13:25-31

> Branton M, Richardson JS (2011) Assessing the value of the umbrella-species concept for conservation planning with meta-analysis. Conserv Biol 25:9-20

Burke L, Spalding M (2011) Reefs at risk. World Resources Institute, Washington, DC

> Butler SJ, Freckleton RP, Renwick AR, Norris K (2012) An objective, niche-based approach to indicator species selection. Methods Ecol Evol 3:317-326

- Campagna C, Sanderson EW, Coppolillo PB, Falabella V, Piola AR, Strindberg S, Croxall JP (2007) A species approach to marine ecosystem conservation. Aquat Conserv 17:122-147

> Cardillo M, Mace GM, Jones KE, Bielby J and others (2005) Multiple causes of high extinction risk in large mammal species. Science 309:1239-1241

> Carlton JT, Geller JB, Reaka-Kudla ML, Norse EA (1999) Historical extinctions in the sea. Annu Rev Ecol Syst 30: 515-538

> Caro TM, O'Doherty G (1999) On the use of surrogate species in conservation biology. Conserv Biol 13:805-814

> Chateau O, Wantiez L (2007) Site fidelity and activity patterns of a humphead wrasse, Cheilinus undulatus (Labridae), as determined by acoustic telemetry. Environ Biol Fishes 80:503-508

Choat JH, Davies CR, Ackerman JL, Mapstone BD (2006) Age structure and growth in a large teleost, Cheilinus undulatus, with a review of size distribution in labrid fishes. Mar Ecol Prog Ser 318:237-246
Colin PL (2010) Aggregation and spawning of the humphead wrasse, Cheilinus undulatus (Pisces: Labridae): general aspects of spawning behaviour. J Fish Biol 76:987-1007

> Coppolillo P, Gomez H, Maisels F, Wallace R (2004) Selection criteria for suites of landscape species as a basis for site-based conservation. Biol Conserv 115:419-430

> Davidson AD, Hamilton MJ, Boyer AG, Brown JH, Ceballos G (2009) Multiple ecological pathways to extinction in mammals. Proc Natl Acad Sci USA 106:10702-10705

> Di Franco A, Gillanders BM, De Benedetto G, Pennetta A, De Leo GA, Guidetti P (2012) Dispersal patterns of coastal fish: implications for designing networks of marine protected areas. PLoS ONE 7:e31681

Doney SC, Fabry VJ, Feely RA, Kleypas JA (2009) Ocean acidification: the other $\mathrm{CO}_{2}$ problem. Ann Rev Mar Sci $1: 169-192$

> Dulvy NK, Sadovy Y, Reynolds JD (2003) Extinction vulnerability in marine populations. Fish Fish 4:25-64

> Dulvy NK, Ellis JR, Goodwin NB, Grant A, Reynolds JD, Jennings $S$ (2004) Methods of assessing extinction risk in marine fishes. Fish Fish 5:255-276

- Fabinyi M (2012) Historical, cultural and social perspectives on luxury seafood consumption in China. Environ Conserv 39:83-92

Fernandes L, Day J, Lewis A, Slegers S and others (2005) Establishing representative no-take areas in the Great Barrier Reef: large-scale implementation of theory on marine protected areas. Conserv Biol 19:1733-1744

Friedlander AM, DeMartini EE (2002) Contrasts in density, size, and biomass of reef fishes between the northwestern and the main Hawaiian islands: the effects of fishing down apex predators. Mar Ecol Prog Ser 230: 253-264

Friedlander A, Nowlis JS, Sanchez JA, Appeldoorn R and others (2003) Designing effective marine protected areas in Seaflower Biosphere Reserve, Colombia, based on biological and sociological information. Conserv Biol 17: 1769-1784

Friedlander AM, Brown E, Monaco ME (2007) Defining reef fish habitat utilization patterns in Hawaii: comparisons between marine protected areas and areas open to fishing. Mar Ecol Prog Ser 351:221-233

Graham NAJ, Chabanet P, Evans RD, Jennings S and others (2011) Extinction vulnerability of coral reef fishes. Ecol Lett 14:341-348

Green AL, Fernandes L, Almany G, Abesamis R and others (2014) Designing marine reserves for fisheries management, biodiversity conservation, and climate change adaptation. Coast Manage 42:143-159

Hall RJ, Milner-Gulland E, Courchamp F (2008) Endangering the endangered: the effects of perceived rarity on species exploitation. Conserv Lett 1:75-81

Harnik PG, Lotze HK, Anderson SC, Finkel ZV and others (2012) Extinctions in ancient and modern seas. Trends Ecol Evol 27:608-617

Harris J (2012) Conserving imperiled species: a comparison of the IUCN Red List and U.S. Endangered Species Act. Conserv Lett 5:64-72

- Heupel MR, Simpfendorfer CA, Hueter RE (2004) Estimation of shark home ranges using passive monitoring techniques. Environ Biol Fishes 71:135-142

Heupel MR, Simpfendorfer CA, Collins AB, Tyminski JP (2006) Residency and movement patterns of bonnethead sharks, Sphyrna tiburo, in a large Florida estuary. Environ Biol Fishes 76:47-67 
Hobbs JPA, Jones GP, Munday PL (2011) Extinction risk in endemic marine fishes. Conserv Biol 25:1053-1055

IUCN (2010) Workshop report on the trade of Cheilinus undulatus (humphead wrasse / Napoleon wrasse) \& CITES implementation. SC61 Doc. 49, IUCN, Bali

IUCN \& UNEP (International Union for Conservation of Nature \& United Nations Environmental Program) (2009) The World Database on Protected Areas (WDPA). UNEPWCMC, Cambridge

$>$ Johannes RE (1998) The case for data-less marine resource management: examples from tropical nearshore finfisheries. Trends Ecol Evol 13:243-246

Johannes RE, Riepen M (1995) Environmental economic and social implications of the live reef fish trade in Asia and the western Pacific. In: Report to The Nature Conservancy and the Forum Fisheries Agency, Vol 83. The Nature Conservancy, Jakarta Selatan

King MC, Beazley KF (2005) Selecting focal species for marine protected area network planning in the ScotiaFundy region of Atlantic Canada. Aquat Conserv 15: 367-385

Kleypas JA, Buddemeier RW, Archer D, Gattuso JP, Langdon C, Opdyke BN (1999) Geochemical consequences of increased atmospheric carbon dioxide on coral reefs. Science 284:118-120

Kramer DL, Chapman MR (1999) Implications of fish home range size and relocation for marine reserve function. Environ Biol Fishes 55:65-79

Lambeck RJ (1997) Focal species: a multi-species umbrella for nature conservation. Conserv Biol 11:849-856

Lindholm J, Knight A, Kaufman L, Miller S (2006) Site fidelity and movement of the parrotfishes Scarus coeruleus and Scarus taeniopterus at Conch Reef (northern Florida Keys). Caribb J Sci 42:138-144

> Liu M, Sadovy de Mitcheson Y (2011) Forehead morphology of the humphead wrasse Cheilinus undulatus (Perciformes: Labridae) in relation to body size. Copeia 315-318

McLeod E, Salm R, Green A, Almany J (2009) Designing marine protected area networks to address the impacts of climate change. Front Ecol Environ 7:362-370

Micheli F, Halpern BS, Botsford LW, Warner RR (2004) Trajectories and correlates of community change in no-take marine reserves. Ecol Appl 14:1709-1723

Moffitt EA, Botsford LW, Kaplan DM, O'Farrell MR (2009) Marine reserve networks for species that move within a home range. Ecol Appl 19:1835-1847

Musick J, Harbin M, Berkeley S, Burgess G and others (2000) Marine, estuarine, and diadromous fish stocks at risk of extinction in North America (exclusive of Pacific salmonids). Fisheries (Bethesda, MD) 25:6-30

> Naeem S, Duffy JE, Zavaleta E (2012) The functions of biological diversity in an age of extinction. Science 336: 1401-1406

Nicholson E, Westphal MI, Frank K, Rochester WA, Pressey RL, Lindenmayer DB, Possingham HP (2006) A new method for conservation planning for the persistence of multiple species. Ecol Lett 9:1049-1060

Nicholson E, Lindenmayer DB, Frank K, Possingham HP (2013) Testing the focal species approach to making conservation decisions for species persistence. Divers Distrib 19:530-540

> Noss RF, Quigley HB, Hornocker MG, Merrill T, Paquet PC (1996) Conservation biology and carnivore conservation in the Rocky Mountains. Conserv Biol 10:949-963
Olden JD, Hogan ZS, Zanden M (2007) Small fish, big fish, red fish, blue fish: size-biased extinction risk of the world's freshwater and marine fishes. Glob Ecol Biogeogr 16:694-701

> Orr JC, Fabry VJ, Aumont O, Bopp L and others (2005) Anthropogenic ocean acidification over the twenty-first century and its impact on calcifying organisms. Nature 437:681-686

> Palumbi SR (2004) Marine reserves and ocean neighborhoods: the spatial scale of marine populations and their management. Annu Rev Environ Resour 29:31-68

> Poh TM, Fanning LM (2012) Tackling illegal, unregulated, and unreported trade towards humphead wrasse (Cheilinus undulatus) recovery in Sabah, Malaysia. Mar Policy 36:696-702

Power ME, Tilman D, Estes JA, Menge BA and others (1996) Challenges in the quest for keystones. Bioscience 46: 609-620

Price SA, Gittleman JL (2007) Hunting to extinction: biology and regional economy influence extinction risk and the impact of hunting in artiodactyls. Proc R Soc B 274: 1845-1851

> Purvis A, Gittleman JL, Cowlishaw G, Mace GM (2000) Predicting extinction risk in declining species. Proc R Soc B 267:1947-1952

Randall JE, Head SM, Sanders APL (1978) Food habits of the giant humphead wrasse, Cheilinus undulatus. Environ Biol Fishes 3:235-238

R Core Team (2013) R: a language and environment for statistical computing. R Foundation for Statistical Computing, Vienna. http://cran.r-project.org

Reynolds JD, Dulvy NK, Goodwin NB, Hutchings JA (2005) Biology of extinction risk in marine fishes. Proc R Soc B 272:2337-2344

> Richards BL, Williams ID, Vetter OJ, Williams GJ (2012) Environmental factors affecting large-bodied coral reef fish assemblages in the Mariana Archipelago. PLoS ONE $7: \mathrm{e} 31374$

Roberge JM, Angelstam P (2004) Usefulness of the umbrella species concept as a conservation tool. Conserv Biol 18: 76-85

Roberts CM, McClean CJ, Veron JEN, Hawkins JP and others (2002) Marine biodiversity hotspots and conservation priorities for tropical reefs. Science 295:1280-1284

Rosen GE, Smith KF (2010) Summarizing the evidence on the international trade in illegal wildlife. EcoHealth 7 : 24-32

Sadovy Y, Cheung WL (2003) Near extinction of a highly fecund fish: the one that nearly got away. Fish Fish 4 : 86-99

> Sadovy Y, Kulbicki M, Labrosse P, Letourneur Y, Lokani P, Donaldson TJ (2003a) The humphead wrasse, Cheilinus undulatus: synopsis of a threatened and poorly known giant coral reef. Rev Fish Biol Fish 13:327-364

Sadovy YJ, Donaldson TJ, Graham TR, McGilvray F and others (2003b) While stocks last: the live reef food fish trade. Asian Development Bank, Manila

Sadovy de Mitcheson Y, Cornish A, Domeier M, Colin PL, Russell M, Lindeman KC (2008) A global baseline for spawning aggregations of reef fishes. Conserv Biol 22: 1233-1244

Sadovy de Mitcheson Y, Liu M, Suharti S (2010) Gonadal development in a giant threatened reef fish, the humphead wrasse Cheilinus undulatus, and its relationship to international trade. J Fish Biol 77:706-718 
Saetersdal M, Gjerde I (2011) Prioritising conservation areas using species surrogate measures: consistent with ecological theory? J Appl Ecol 48:1236-1240

Sanderson EW, Redford KH, Vedder A, Coppolillo PB, Ward SE (2002) A conceptual model for conservation planning based on landscape species requirements. Landsc Urban Plan 58:41-56

Sandin SA, Smith JE, DeMartini EE, Dinsdale EA and others (2008) Baselines and degradation of coral reefs in the northern Line Islands. PLoS ONE 3:e1548

Shanks AL, Grantham BA, Carr MH (2003) Propagule dispersal distance and the size and spacing of marine reserves. Ecol Appl 13:159-169

Simpfendorfer CA, Heupel MR, Hueter RE (2002) Estimation of short-term centers of activity from an array of omnidirectional hydrophones and its use in studying animal movements. Can J Fish Aquat Sci 59:23-32

Stelzenmuller V, Lee J, South A, Foden J, Rogers SI (2013) Practical tools to support marine spatial planning: a review and some prototype tools. Mar Policy 38:214-227

Thornton M (2009) Cantillon and the invisible hand. Q J Austrian Econ 12:27-46

Weaver JL, Paquet PC, Ruggiero LF (1996) Resilience and

Editorial responsibility: Eric Gilman,

Honululu, Hawaii, USA conservation of large carnivores in the Rocky Mountains. Conserv Biol 10:964-976

- Weeks R, Alino PM, Atkinson S, Beldia P and others (2014) Developing marine protected area networks in the coral triangle: good practices for expanding the Coral Triangle marine protected area system. Coast Manage 42:183-205

> Weng KC, Castilho PC, Morrissette JM, Landiera-Fernandez A and others (2005) Satellite tagging and cardiac physiology reveal niche expansion in salmon sharks. Science 310:104-106

Wiens JA, Hayward GD, Holthausen RS, Wisdom MJ (2008) Using surrogate species and groups for conservation planning and management. Bioscience 58:241-252

Worton BJ (1989) Kernel methods for estimating the utilization distribution in home-range studies. Ecology 70 : 164-168

Z Zacharias MA, Roff JC (2001) Use of focal species in marine conservation and management: a review and critique. Aquat Conserv 11:59-76

Zgliczynski B, Williams I, Schroeder R, Nadon M, Richards B, Sandin S (2013) The IUCN Red List of threatened species: an assessment of coral reef fishes in the US Pacific Islands. Coral Reefs 32:637-650

Submitted: July 10, 2014; Accepted: November 28, 2014 Proofs received from author(s): April 7, 2015 